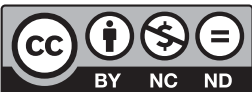

Estudos Teológicos foi licenciado com uma Licença Creative Commons Atribuição - NãoComercial - SemDerivados 3.0 Não Adaptada

http://dx.doi.org/10.22351/et.v58i2.3439

\title{
Prayers of the Precariat? The Political Role of Religion in Precarious Times ${ }^{1}$
}

\author{
Orações do Precariato? \\ O papel político de religião em tempos precários
}

Sturla J. Stålsett ${ }^{2}$

\begin{abstract}
This article presents and discusses Guy Standing's use of the concept the 'precariat,' and its possible usefulness when analyzing the role of religion in present political crises. Combining the classic Marxist concept of the 'proletariat' with diverse experiences of precariousness in a globalized world such as social exclusion, part-time and insecure work, and migration, the term 'precariat' is presented as a suggestive socio-analytic tool. Standing's use of this neologism is also criticized, however, in particular for signaling certain social groups as 'dangerous', thus arguably revealing an implicit, Eurocentric and colonizing bias. Neither Standing nor his critics address the role of religion in a relationship with the precariat. Hence, referring to the sociological work of Inglehart and Norris on the increasing relevance of religiosity in precarious living conditions, this article poses the challenge of analyzing in what ways different kinds of religiosity (fundamentalist, charismatic, liberationist) may be seen to affect the precariat and political processes to overcome precarization.
\end{abstract}

Keywords: Precariat. Vulnerability. Work. Religion and politics. Guy Standing.

Resumo: Este artigo apresenta e discute o uso de Guy Standing do conceito "precariato" e sua possível utilidade ao analisar o papel da religião nas atuais crises políticas. Combinando o conceito clássico marxista do "proletariado" com várias experiências de precariedade num mundo globalizado como exclusão social, trabalho de tempo parcial ou inseguro, e migração, o termo "precariato" é apresentado como uma ferramenta socioanalítica sugestiva. O uso de Standing desse neologismo, porém, também é criticado, em particular, por apontar certos grupos sociais como "perigosos", assim indiscutivelmente revelando um viés implícito, eurocêntrico e colonizador. Nem Standing nem seus críticos abordam o papel da religião em um relacionamento com o precariato. Portanto, referindo-se ao trabalho sociológico de Inglehart e Norris sobre a crescente relevância da religiosidade nas condições precárias de vida, este artigo coloca o desafio

1 O artigo foi recebido em 27 de agosto de 2018 e aprovado em 17 de outubro de 2018 com base nas avaliações dos pareceristas ad hoc.

2 Doutor em Teologia pela Universidade de Oslo. Professor de Religião, Sociedade e Estudos Diaconais na MF Escola Norueguesa de Teologia, Religião e Sociedade em Oslo, Noruega. Contato: sturla.stalsett@mf.no 
de analisar de que maneiras tipos diferentes de religiosidade (fundamentalista, carismático, libertacionista) podem ser vistos como afetando os processos políticos e de precariato para superar a precarização.

Palavras-chave: Precariato. Vulnerabilidade. Trabalho. Religião e Política. Guy Standing.

\section{Introduction}

\section{Precarious times?}

We set out to explore the political role of religion in precarious times. But what are 'precarious times'? And is this what we are experiencing now?' 'Precarious' has a double connotation. ${ }^{4}$ It signals both urgency and vulnerability. Something is about to break down. Someone, or rather, many find themselves in a situation where they feel exposed and endangered, being handed over to, or being completely in the hands of, someone or something else.

This experience of insecurity or lack of control can certainly occur at a very personal or individual level. It may be a question of health, physical or mental. Accidents may and do happen, and they can hit us like lightning from a clear blue sky. In such situations, existential and religious questions come to the fore, both personally and institutionally. Churches, pastors, priests, deacons as well as other faith-based communities and institutions are all dealing with this experience of precariousness. Thus, these personal experiences are brought into a communal sphere. Through consolation and consultation; through liturgies, celebrations, and funerals as well as pastoral and diaconal programs; people seek to come to terms with precarious lives.

In our hyper-technological age, we are still handed over to meteorological conditions beyond our control. Many, probably hundreds, of persons are reported to have frozen to death in Europe in the cold winter of 2017-18. During the following summer, drought and forest fires took more lives and caused great losses and damages. All such experiences of being exposed, being handed over to forces beyond our control, also have a political dimension. Our precarious lives are political, too. Acts of terrorism, refugee crises, extreme economic inequality, and the rise of authoritarianism are signs of the times. The situation seems to be rapidly getting worse. Politics is polarized. Outbreaks of violence or the fear of such violence is threatening the basic

3 This article is a revised version of my opening lecture at the seminar "Precious and Precarious: Precarious Life, Fragile Democracy and the Role of Religiosity and the Churches" at the Faculdades EST on the 19th of March 2018. This was part of a joint Master's course with the same title realised in the 1st semester of 2018, in collaboration between Faculdades EST and MF - Norwegian School of Theology, Religion and Society. The first part took place in São Leopoldo, the second part in Oslo. I thank colleagues at EST, in particular prof. André Musskopf and prof. Rudolf von Sinner for excellent cooperation on this course.

4 Oxford dictionaries defines 'precarious' thus: "Not securely held or in position; dangerously likely to fall or collapse", or “dependent on chance; uncertain". Some of the synonyms listed are: "Uncertain, insecure, unreliable, unsure, unpredictable, undependable, risky, hazardous, dangerous, unsafe,..." See: <https:// en.oxforddictionaries.com/definition/precarious>. Accessed: 14 March 2018. 
democratic and civil structures of society. Populism thrives, and a culture of corruption and distrust spreads. ${ }^{5}$

In such times, many people turn to religion. They do so not just for personal comfort. They mobilize their faith resources in the public sphere and on the political arena. Religious practices, as well as religious beliefs, thus gain a new relevance for the study of present-day politics. ${ }^{6}$

\section{Times of crisis?}

So, are these times of crisis? Although the answer may seem obvious, we should pause before concluding. Our global, regional and national contexts are indeed complex and diverse. Furthermore, the very act of declaring a situation as one of crisis is a political tool that may easily be misused to legitimize political measures or actions that are undemocratic. Appeal to a crisis or an overwhelming danger has often prepared the way for extreme use of oppressive power. Exceptional situations call for exceptional actions. In our time, the state of exception is becoming normalized, the Italian philosopher Giorgio Agamben claims: " “...it not only appears increasingly as a technique of government rather than an exceptional measure, but also lets its nature as the constitutive paradigm of the juridical order come to light." ${ }^{8}$ In her book, The Shock Doctrine, Naomi Klein draws critical attention to such dynamics, in particular within the field of economic policies. ${ }^{9}$ It is even more relevant in issues of security policy - perceived or real. In Norway, for instance, during what came to be ambiguously ${ }^{10}$ called the refugee crisis in 2015-2016 led to a rapid parliamentary decision to restrict asylum-rights through measures and rhetoric which a few months earlier was

5 See e.g. MÜLlER, Jan-Werner. What Is Populism? Philadelphia: University of Pennsylvania, 2016; TAGGART, Paul A. Populism, Concepts in the Social Sciences. Buckingham: Open University, 2000; FUKUYAMA, Francis. Identity: Contemporary Identity Politics and the Struggle for Recognition. London: Profile, 2018.

6 Cf. the return of religion within the study of international relations, in e.g. HAYNES, Jeff. Religion in Global Politics. London; New York: Longman, 1998; APPLEBY, Scott. The Ambivalence of the Sacred. Religion, Violence, and Reconciliation. Lanham; Boulder; New York; Oxford: Rowman \& Littlefield, 2000; SCOTT, Thomas. Religion and International Society. In: HAYNES, Jeff (ed.). Religion, Globalization and Political Culture in the Third World. Basingstoke: Macmillan, 1999; STÅLSETT, Sturla J. (ed.). Religion in a Globalised Age: Transfers and Transformations, Integration and Resistance. Oslo: Novus, 2008; STÅLSETT, Sturla J.; LEIRVIK, Oddbjørn. The Power of Faiths in Global Politics. Oslo: Novus, 2004; BUTLER, Judith; MENDIETA, Eduardo; VANANTWERPEN, Jonathan. The Power of Religion in the Public Sphere. New York: Columbia University, 2011; HURD, Elizabeth Shakman. The Politics of Secularism in International Relations. Princeton, N.J.; Oxford: Princeton University, 2008.

7 AGAMBEN, Giorgio. State of Exception. Chicago: University of Chicago, 2005. Agamben refers to what Walter Benjamin wrote during World War II: "the state of exception... has become the rule". BENJAMIN, W. Über den Begriff der Geschichte. 1942 apud AGAMBEN, 2005, p. 6.

8 AGAMBEN, 2005, p. 7.

9 KLEIN, Naomi. The Shock Doctrine: The Rise of Disaster Capitalism. New York: Metropolitan, 2007.

${ }^{10}$ In the first phase, the word 'crisis' seemed to refer to the situation of the refugees and the asylum seekers. Then, the general understanding quite swiftly changed: Now the situation was primarily a crisis for Europe who was on the receiving end of migration. 
generally held to belong exclusively to the political right-wing. It was a clear shift in Norwegian policy about refugee rights, and can be seen as an immediate 'shock treatment' to send a double 'signal': On the one hand, to the potential and actual refugees that they were not welcome. And, on the other hand to the population, that the national authorities maintain control over the situation. ${ }^{11}$

Nonetheless, our times constitute a situation of crisis in several respects. There is a considerable part of the population, globally as well as both in Latin America and in Europe, that experience a lack of basic security. The situation is critical for many people, not only refugees. Whether or not these groups should be designated 'the precariat' ${ }^{12}$ as an alternative to, e.g. 'the multitude' ${ }^{13}$ or more general 'the marginalized', 'the poor' or 'the vulnerable, ${ }^{14}$ their situation is characterized by risk and hardships of different kinds. Secondly, as Ulrich Schmiedel and Graeme Smith accurately point out in their compilation about religion in European the refugee crisis, crisis means - etymologically - a time for decision: Either this way or that way. ${ }^{15}$ Recent developments in world politics, from climate crisis to populism on the rise, indicate that the time is ripe for making hard choices: This way or that way.

\section{Kairos and the role of religion in times of crisis}

Such a call for "a strong and striking decision"16 recalls the biblical notion of Kairos, a time of opportunity, a time for action. This notion has been in central in church action for justice, supported by liberation theologies and public theologies. Prominent here are the South African Kairos document from 1985, the Central American Kairos document from 1986, the Road to Damascus-document from 1989, and the Moment of Truth, Palestinian Kairos document from 2009. As Kjetil Fretheim argues in his book Interruption and Imagination, these documents represent important

11 STÅLSETT, Sturla J. Fearing the Faith of Others? On Government, Religion and Integration - the Case of Norway. SCHMIEDEL, U.; SMITH, G. (eds.). Religion in the European Refugee Crisis. Basingstoke: Palgrave Macmillan, 2018.

12 STANDING, Guy. The Precariat: The New Dangerous Class. London: Bloomsbury Publishing, 2011. Portuguese version: O Precariado: A Nova Classe Perigosa. Trad. Cristina Antunes. Belo Horizonte; São Paulo: Autêntica, 2013.

${ }^{13}$ HARDT, Michael; NEGRI, Antonio. Empire. Cambridge; London: Harvard University, 2000; BROWN, Nicholas; IMRE, Szeman. O que é a multidão? Questões para Michael Hardt e Antonio Negri. Novos Estudos CEBRAP, n. 75, 2006; HARDT, Michael; NEGRI, Antonio. Multitude: War and Democracy in the Age of Empire. New York: Penguin, 2004; RIEGER, Joerg; KWOK, Pui-lan. Occupy Religion: Theology of the Multitude, Religion in the Modern World. United States: Rowman \& Littlefield, 2012.

${ }^{14}$ See e.g. STÅLSETT, Sturla J. Vulnerabilidad, dignidad y justicia: Valores éticos fundamentales en un mundo globalizado. Pasos, n. 111, 2004; The Ethics of Vulnerability, Social Inclusion and Social Capital. Forum for development studies 34, n. 1, 2007; Towards a Political Theology of Vulnerability: Anthropological and Theological Propositions. Political Theology 16, n. 5, 2015.

15 SCHMIEDEL, Ulrich; SMITH, Graeme (eds.). Religion in the European Refugee Crisis. Basingstoke: Palgrave Macmillan, 2018. p.3-9.

16 SCHMIEDEL; SMITH (eds.), 2018. p. 297. 
examples of how faith-based communities can take action in the public sphere vis-à-vis extraordinary circumstances, i.e., in times of crisis. ${ }^{17}$

Precarious times may constitute a Kairos, a time for decision and action in which faith resources play an important role. As part of the investigation of the more overarching question to what degree and in what ways this is the case now, I shall now focus on one recent and controversial description of those primarily affected by the present crises, namely the 'precariat.' First, I explore the content and adequacy of this designation. What could be seen as strengths and weaknesses of this terminology? In line with the critical edge of de-colonization theories, we also have to ask to what degree this notion makes sense from the perspective of 'the global South.' Second, I examine some of its possible implications for the study of religion in society and theology. I note an absence of analyses of the precariat's possible use of religious resources and ask what kind of religiosity may seem to be relevant to the precariat.

\section{What is the precariat?}

\section{Background}

Combining the two words 'precarious' and 'proletariat' was first done in French sociology in the 1970's. But the present-day debate around this concept is due to the innovative and influential promotion of it by Guy Standing who is professor Economic Security of the University of Bath, UK. Standing, a former long-time senior official in the International Labour Organization (ILO), is strongly advocating the need for understanding new configurations and transformations of work under and after the age of globalization. Following his Work After Globalization (2009) ${ }^{18}$, Standing in 2011 takes a bolder, more rhetorically powerful approach, when he launches the idea of a 'new class' or 'emergent class' in The Precariat: The New Dangerous Class (2011). ${ }^{19}$ Standing's proposal received enthusiasm and criticism. Some criticized it for being 'old news,' and for being too vague and even misleading. Most critically, the designation 'dangerous class' received harsh criticisms, as we shall see. Still, with this conceptualization, Standing has managed to raise awareness about significant transformations that seem to take place in our present time, and that challenge societies, politics, and hence also faith-based communities globally. His concept was not meant as purely academic. In the sequel A Precariat Charter: From Denizens to Citizens (2014) Standing proceeds to propose concrete new policies. ${ }^{20}$

17 FRETHEIM, Kjetil. Interruption and Imagination: Public Theology in Times of Crisis. Eugene, Or: Pickwick, 2016. p. 73.

18 STANDING, Guy. Work after Globalization: Building Occupational Citizenship. Cheltenham: Edward Elgar, 2009.

19 STANDING, 2011. Cf. STANDING, Guy. O precariado e a luta de classes. Revista Crítica de Ciências Sociais, n. 103, 2014.

20 STANDING, Guy: A Precariat Charter: From Denizens to Citizens. London; New York: Bloomsbury Academic, 2014. 


\section{Definition}

The precariat can be defined in at least two ways, according to Standing. It can be seen as a socio-economic group to which a person belongs according to certain criteria. But it can also be seen as a class-in-the-making, although yet not a class in itself in a purely Marxist understanding. Standing alludes to both. He accepts André Gorz's thesis about the 'end of the working class,' and argues that we hence need a new vocabulary to describe and understand class relations in the $21^{\text {st }}$ century. The precariat then is the globally growing group of people or class that is experiencing an increasing lack of security related to work and thereby to daily living between survival and welfare. More concretely, the precariat consists of people who lack what Standing lists as the seven different forms of labor-related security: labor market security, employment security, job security, work security, skill reproduction security, income security, and representation security. In short, then, the precariat are people with insecure jobs, inside, on the margins of, or completely outside the formal labor market. They have different characteristics and backgrounds. One group, according to Standing, consists of people "bumped out of working-class communities and families," who experience a "relative deprivation" gradually having lost the "status skill and respect" enjoyed by their parents and grandparents who belonged to working-class occupations. ${ }^{21}$ This group may be prone to accepting populist and even neo-fascist agendas, blaming other people, particularly migrants for their decreased status and more insecure life conditions. The second group is exactly these 'other people,' in particular, 'the migrants, Roma, ethnic minorities, asylum seekers in limbo, all those with the least secure rights anywhere." 22 This group also experiences an increasing loss of basic security. Since they are without rights or only have limited rights, Standing calls them 'denizens' as opposed to 'citizens.' The most obvious representatives of this group are the undocumented migrants, who lack basic respect for their rights since they do not fully belong to the polity, under the responsibility of a state. They lay bare, as also Agamben points out in another context, that human rights are both from its origins and for all practical purposes, actually citizens' rights. So, not being legal citizens, but denizens, they have to keep their heads down, and be content with whatever survival strategy, inside or outside of legality. ${ }^{23}$

A third group of the precariat, however, starts at the other end of the social hierarchy. These often young and educated persons have ended up in the insecurity of the precariat in spite of good and promising prospects of a professional career. They do not get access to do what they are trained to do, and for what they are aspiring. Frustration and depression linked to social loss of status and prospects characterize this group.

${ }^{21}$ STANDING, 2014, p. 29.

22 STANDING, 2014, p. 29.

${ }^{23}$ BYMISJON, Kirkens. Undocumented Migration, Human Trafficking and the Roma. Manifestations of Irregular Migration and Exclusion in Norway, Shortcomings in Governance, and Implications for Health, Well-Being and Dignity. Oslo: The Oslo Church City Mission, 2013. 


\section{'Dangerous class'? Criticism from the South}

So the precariat, according to Standing, is manifold. It is global. It consists of more women than men, more young people than elderly. Importantly, it is a group or class in internal tension. Although they share the experience of precarious relations, or lack of relations, to formal and secure work to sustain their daily living and social status, they may not necessarily have common solutions to these challenges. And even if there should be, as Standing seeks to establish, coherent and viable political strategies for improving the situation of the precariat as such, there is, as Standing also points out, not surprisingly a lack of common understanding among the diverse members of the precariat. There is, in other words, a lack of understanding among people belonging to the precariat that their vulnerability is something that they have in common; something that they share. Furthermore, Standing points to a lack of trust, collaboration, and solidarity, which is necessary to take common action against the global and national processes of precarization. Principally, this is why the precariat to Standing also is 'a dangerous class:' It may resign totally from political action, or easily fall prey to populist and neo-fascist political forces.

This last designation, of the precariat being a dangerous class, has been harshly criticized. In a thorough critique of Standing 'from the South' (although a Professor in Dublin), Ronaldo Munck, writes:

The politics of a 'dangerous class' discourse is, I would argue, quite simply incompatible with a progressive social transformation politics. It is a politics of social pathology which has no place in a progressive view of history and human potential. [...] Thus, as a political strategy for the 21 st century, to even pose an emerging precariat as a new dangerous class is politically irresponsible at the very least. Nor is it even impressionistically accurate to pose recruitment of the 'precariat' by the new racist right as an imminent danger. In fact the European and other emerging racist and fascist formations are appealing more to the 'old' working class displaced by the ongoing economic crisis. ${ }^{24}$

In general, Ronaldo Munck faults Standing's use of the term 'precariat' for misunderstanding the complexity of class making and remaking. He thinks the term is "of dubious political purchase", and even "acts as a colonising concept in the South in classic Eurocentric mode." 25 Standing's use of the term precariat overlooks that the global working class is far from having disappeared, in fact, has increased in size, although its characteristics have changed. It also overlooks important theoretical tools developed in the South that may facilitate much better understanding and action to overcome the present weakness of globalized precarious work to which Standing rightly, Munck admits - wishes to raise awareness.

\footnotetext{
${ }^{24}$ MUNCK, Ronaldo. The Precariat: A View from the South. Third World Quarterly 34, n. 5, 2013.

25 MUNCK, 2013.
} 
Another critic, Richard Seymour, finds that the concept of 'the precariat' "unconvincing" and "impressionistic." ${ }^{26}$ However, the concept, as he sees it, "...is an interpellation that can help in forming a new, radical majoritarian politics with and anticapitalist core. The precariat is not a dangerous, exotic, alien thing, not an incipient class to be patronized into existence. It is all of us." 27

Munck does not think much of this generalization by Seymour, that 'we are all' part of the precariat now. It does certainly seem to dissolve the analytical worth of the concept. The critical point that Munck and Seymour share, however, is that calling the precariat 'dangerous' may add to the stigmatization that serves to exclude and even demonize it. That, of course, is not Standing's intention. He seeks to point to the paradoxical political agency of the precariat - actual or potential.

This potential political agency, when faced with precarious situations, is to me the most interesting and incisive dimension of Standing's renewal of the concept the 'precariat.' Here is where an analysis of how religion and religiosity relate to the precariat should begin. Neither Standing nor his critics address this role of religion related to precarious life situations in particular.

\section{The Religiosity of the Precariat?}

\section{Religiosity, secularization and the experience of vulnerability}

What, if any, is the preferred religiosity of the precariat? The experience of exposure, insecurity, and vulnerability - in a word, experiences of life as precarious - tend to increase the significance of religiosity and faith to people. Criticizing both the standard secularisation thesis, and its reversal, the thesis about a de-secularisation (or even re-sacralization) of the world, ${ }^{28}$ the sociologists of religion Pippa Norris and Ronald Inglehart have shown convincingly that the more people feel exposed to lack of security in their everyday lives, the more religious they tend to be. And, the other way round, the more people are experiencing a high degree of welfare and human security, the more secular they tend to be. In their own words:

We believe that the importance of religiosity persists most strongly among vulnerable populations, especially those living in poorer nations, facing personal survival-threatening risks. We argue that feelings of vulnerability to physical, societal, and personal risks are a key factor driving religiosity and we demonstrate that the process of secularization - a systemic erosion of religious practices, values, and beliefs - has occurred

${ }^{26}$ SEYMOUR, Richard. We Are All Precarious - on the Concept of the 'Precariat' and Its Misuses. New Left Project, 2012, p. 1.

27 SEYMOUR, 2012, p. 1.

${ }^{28}$ See e.g. BERGER, Peter L. The Desecularization of the World: Resurgent Religion and World Politics. Washington D.C.: Ethics and Public Policy Center, 1999. 
most clearly among the most prosperous social sectors living in affluent and secure post-industrial nations. ${ }^{29}$

If they are right, this means that the precariat would be likely to turn to religion. Neither Standing nor his critics show any interest in this. Rather, Standing seems to be more aware of the lack of hope, and lack of sources of resilience and resistance, within the precariat. Indeed, as his critics point out, Standing's understanding of the precariat is based more on what it lacks (security) than what it has (resources). Inglehart and Norris are right in pointing out that religiosity and faith practices of very different forms and contents do respond to experiences of vulnerability. But they do not help us to understand why, how, and with what effect. If religiosity becomes a resource to the precariat, this resource may be as ambivalent and contradictory as the precariat itself. There is not one particular or predestined effect of religiosity on political precariousness.

\section{Protecting precariousness}

In my book Religion in turbulent times. Globalisation, religiosity and vulnerability (2017) $)^{30} \mathrm{I}$ argue in line with i.a. Judith Butler that vulnerability should not be seen as a weakness to be removed, but rather as a value, or an asset, to be protected. ${ }^{31}$ Life is vulnerable in its core and should be protected as such. Butler argues for "... demanding a world in which bodily vulnerability is protected without therefore being eradicated", and "insisting on the line that must be walked between the two." 32 Without experiencing ourselves as vulnerable, true empathy, ethical action or solidarity is impossible. That is why the common experience of the vulnerability or precariousness of the precariat could be seen as a resource for its common action, and not as something that necessarily should give reason to despair, nor, much less, make the precariat potentially dangerous. In this sense, there is also some truth in what Seymour says: We are all living precarious lives. Still that does not take away the distinct and contextual particularities in each experience of precariousness. Precariousness, or rather precarity, is certainly unevenly distributed. ${ }^{33}$ This is what has to be critically analysed to understand better the causes of as well as the possible and relevant responses to precarization.

Religiosity may be a resource in recognizing this commonality-in-vulnerability, and in re-interpreting the inescapable vulnerability as a possible resource for hu-

\footnotetext{
29 NORRIS, Pippa; INGLEHART, Ronald. Sacred and Secular. Religion and Politics Worldwide. 2 nd ed. New York: Cambridge University, 2011. p. 4-5.

30 STÅLSETT, Sturla J. Religion i urolige tider. Globalisering, religiøsitet og sårbarhet. Oslo: Cappelen Damm Akademisk, 2017. See also STÅLSETT, 2004; 2015.

31 BUTLER, Judith. Precarious Life: The Powers of Mourning and Violence. London; New York: Verso, 2006; Frames of War: When Is Life Grievable? Pbk. ed. London; New York: Verso, 2010.

32 BUTLER, 2006, p. 42.

33 Although apparently not always in a consistent manner, Judith Butler makes the distinction between the precariousness of any life and the uneven and unjust global distribution of precarity. See BUTLER, 2010, p. 1-32.
} 
manizing politics and restoring hope. However, many forms of religiosity do not do this, but rather join in a common political and social trend in denying, despising or seeking to escape from vulnerability as such. So, when research has shown that religiosity becomes more important to people when they experience increased vulnerability, we should ask what different types of religiosity mean to people when experiencing this vulnerability. What could be the preferred (forms of) prayer of the precariat?

\section{Three types of religiosity and their response to vulnerablity}

In Religion in turbulent times (2017) I take up this challenge, focusing on different types of religiosity across the religions, rather than different religions (Christianity, Islam, Hinduism, etc.) I look at three categories: fundamentalist, charismatic, and ecumenical or liberationist religiosities. In brief, I suggest that religious fundamentalists seem to fear and even despise vulnerability. ${ }^{34}$ The charismatic movements often take peoples' vulnerability as their point of departure, offering a kind of religiosity which promises to overcome these challenges with help from spiritual resources, such as prayer, blessings, tithing, exorcism, healing, or the experience of community and mutual strength. ${ }^{35}$

The last category of religiosity which I examine, the ecumenical and liberation-oriented, is often highly critical of economic globalization understood as an increased focus on wealth that creates social inequalities and environmental damage. This group represents different religious groups and types of religiosity. Nevertheless, they share a similar approach to vulnerability. In contrast with the two other religiosity types, this one offers resources to acknowledge and recognize the religious and ethical value of vulnerability. Because of this, I suggest that it is capable of meeting some of the basic challenges many individuals and groups face in precarious times. It would seem to be the most viable alternative for the precariat.

And yet, somewhat paradoxically, in exactly such times of crisis, these kinds of religiosities seem to have more challenges with appeal and mobilization, than the two other categories. As noted above, our time is characterized by polarization, conflict and harsh competition. Fundamentalist approaches may in such a situation seem attractive to people by their clear and absolute message, their moral Manichaeism according to which the absolute good is in a continuous struggle with the absolute evil, ${ }^{36}$ and their firm belief in the infallibility of their doctrines and scriptures. ${ }^{37}$

${ }^{34}$ See e.g. JONES, James William. Terror and Transformation: The Ambiguity of Religion in Psychoanalytic Perspective. Hove: Brunner-Routledge, 2002.

${ }^{35}$ BERGER, Peter L. Max Weber Is Alive and Well, and Living in Guatemala: The Protestant Ethic Today. Review of Faith and International Affairs 8, n. 4, 2010.

${ }^{36}$ APPLEBY, Scott; ALMOND, Gabriel A.; SIVAN, Emmanuel. Fundamentalism: Genus and Species. In: MARTY, Martin E.; APPLEBY, R. Scott (eds.). Fundamentalisms Comprehended. Chicago: The University of Chicago. American Academy of Arts and Sciences, 1995. p. 416; cf. JUERGENSMEYER, Mark. Terror in the Mind of God. The Global Rise of Religious Violence. Updated edition with a new preface. Berkeley; Los Angeles; London: University of California, 2001 (2000).

${ }^{37}$ APPLEBY, ALMOND; SIVAN, 1995, p. 407. 
The appeal of different types of Charismatic religiosity of Pentecostal and Neo-Pentecostal types is related to the fact that they in many ways concur with basic tendencies in global society towards commercialization and competition. Instead of opposing the powerful forces of turbulence in precarious times, they offer spiritual resources to prosper in coalition with them. Such religiosity promises to be 'good for business,' also at the personal level. Without a doubt, many of the groups and leaders involved in charismatic religiosity are in fact good at adapting to and taking advantage of the economic system. ${ }^{38}$ This type of religiosity has a large appeal, especially in societies where people need religiosity to cope with harsh everyday living conditions. But as seen from the perspective of the possible common mobilization of the precariat, this kind of religiosity does not provide resources for critical resistance to the powers that create precarity for increasing numbers of people worldwide. ${ }^{39}$

\section{Final considerations}

To understand better the political role of religion in precarious times such as ours, I have examined Guy Standing's use of the concept 'precariat' for describing an emergent global class of people who experience increasingly precarious living conditions through their exclusion from life-sustaining and stable labor. Seeing this group of people as 'dangerous' as signaled by Standing is not very helpful when seen from a decolonizing perspective from the global south. Rather, focusing on the shared experience of vulnerability and yet the seeming lack of common platform or strategy needed to overcome these conditions, I have pointed to the need for an analysis of the role religious resources plays or might play for the precariat. In a preliminary attempt to meet this need, I suggest that different kinds of religiosity represent different approaches to the experience of precariousness: Fundamentalism denies, despises and seeks to eradicate vulnerability. Charismatic approaches offer to overcome vulnerability with the help of the power of spiritual experiences such as exorcism, healing, and blessing. By contrast, ecumenical and liberationist religiosities offer ways to recognize vulnerability as constitutive for human life and as a paradoxical resource in protecting and sustaining livable life for the precariat. Thus, seen through the lens of a religious worldview, the experience of vulnerability could become the common platform for political action, which Standing finds lacking.

\footnotetext{
38 Among many studies, see e.g. MARTIN, David. Pentecostalism: The World Their Parish, Religion and Modernity. Oxford: Blackwell, 2002; BARRERA RIVERA, Paulo. Tradição, transmissão e emoção religiosa. Sociologia do protestantismo contemporâneo na América Latina. São Paulo: Olho d'Água, 2001; and RUUTH, Anders. Igreja Universal do Reino de Deus. Gudsrikets universella kyrka - En brasiliansk kyrkobildning. Stockholm: Almquist \& Wicksell International, 1995. (Bibliotheca theologiae practicae, Kyrkovetenskapelige studier, v. 54).

39 STÅLSETT, Sturla J. Offering on-Time Deliverance: The Pathos of Neo-Pentecostalism and the Spirits of Gloobalization. STÅLSETT, S. J. (ed.). Spirits of Globalisation. The Growth of Pentecostalism and Experiential Spiritualities in a Global Age. London: SCM, 2006.
} 
These arguments call for empirical grounding in different contexts. Also, the categories (fundamentalist, charismatic, ecumenical) are admittedly imprecise. Nonetheless, I believe such analyses are helpful to understand better both the precarious times in which we are living and the role which religiosity may play in them. The prayers of the precariat may ultimately have unexpected political effects.

\section{References}

AGAMBEN, Giorgio. State of Exception. Chicago: University of Chicago, 2005.

APPLEBY, Scott. The Ambivalence of the Sacred. Religion, Violence, and Reconciliation. Lanham; Boulder; New York; Oxford: Rowman \& Littlefield, 2000.

; ALMOND, Gabriel A.; SIVAN, Emmanuel. Fundamentalism: Genus and Species. In: MARTY, Martin E.; APPLEBY, R. Scott. Fundamentalisms Comprehended. Chicago: The University of Chicago; American Academy of Arts and Sciences, 1995. v. 5, p. 399-424.

BARRERA RIVERA, Paulo. Tradição, Transmissão e Emoção Religiosa. Sociologia do Protestantismo Contemporâneo na América Latina. São Paulo: Olho d'Água, 2001.

BERGER, Peter L. The Desecularization of the World: Resurgent Religion and World Politics. Washington D.C.: Ethics and Public Policy Center, 1999.

. Max Weber Is Alive and Well, and Living in Guatemala: The Protestant Ethic Today. Review of Faith and International Affairs 8, n. 4, p. 3-9, 2010.

BROWN, Nicholas; IMRE, Szeman. O que é a multidão? Questões para Michael Hardt e Antonio Negri. Novos Estudos CEBRAP, n. 75, p. 93-108, 2006.

BUTLER, Judith. Precarious Life: The Powers of Mourning and Violence. London; New York: Verso, 2006.

. Frames of War: When Is Life Grievable? Pbk. ed. London; New York: Verso, 2010.

. MENDIETA, Eduardo; VANANTWERPEN, Jonathan. The Power of Religion in the

Public Sphere. New York: Columbia University, 2011.

BYMISJON, Kirkens. Undocumented Migration, Human Trafficking and the Roma. Manifestations of Irregular Migration and Exclusion in Norway, Shortcomings in Governance, and Implications for Health, Well-Being and Dignity. Oslo: The Oslo Church City Mission, 2013. Retrieved from Oslo: <http://www.med.uio.no/helsam/english/research/global-governance-health/background-papers/oslo-church-city-mission.pdf $>$.

FRETHEIM, Kjetil. Interruption and Imagination: Public Theology in Times of Crisis. Eugene, Or: Pickwick, 2016.

FUKUYAMA, Francis. Identity: Contemporary Identity Politics and the Struggle for Recognition. London: Profile, 2018.

HARDT, Michael; NEGRI, Antonio. Empire. Cambridge; London: Harvard University, 2000.

;__. Multitude: War and Democracy in the Age of Empire. New York: Penguin, 2004. HAYNES, Jeff. Religion in Global Politics. London; New York: Longman, 1998.

HURD, Elizabeth Shakman. The Politics of Secularism in International Relations. Princeton, N.J.; Oxford: Princeton University, 2008.

JONES, James William. Terror and Transformation: The Ambiguity of Religion in Psychoanalytic Perspective. Hove: Brunner-Routledge, 2002.

JUERGENSMEYER, Mark. Terror in the Mind of God. The Global Rise of Religious Violence. Updated edition with a new preface ed. Berkeley; Los Angeles; London: University of California, 2001 (2000).

KLEIN, Naomi. The Shock Doctrine: The Rise of Disaster Capitalism. New York: Metropolitan, 2007. MARTIN, David. Pentecostalism: The World Their Parish. Religion and Modernity. Oxford: Blackwell, 2002.

MUNCK, Ronaldo. The Precariat: A View from the South. Third World Quarterly 34, n. 5, p. 747-762, 2013. 
MÜLLER, Jan-Werner. What Is Populism? Philadelphia: University of Pennsylvania, 2016. NORRIS, Pippa; INGLEHART, Ronald. Sacred and Secular. Religion and Politics Worldwide. 2nd ed. New York: Cambridge University, 2011.

RIEGER, Joerg; KWOK, Pui-lan. Occupy Religion: Theology of the Multitude. Religion in the Modern World. United States: Rowman \& Littlefield, 2012.

RUUTH, Anders. Igreja Universal do Reino de Deus. Gudsrikets Universella Kyrka - En Brasiliansk Kyrkobildning. Stockholm: Almquist \& Wicksell International, 1995. (Bibliotheca Theologiae Practicae, Kyrkovetenskapelige Studier, v. 54).

SCHMIEDEL, Ulrich; SMITH, Graeme (eds.). Religion in the European Refugee Crisis. Basingstoke: Palgrave Macmillan, 2018.

SCOTT, Thomas. Religion and International Society. In: HAYNES, J. (ed.). Religion, Globalization and Political Culture in the Third World. Basingstoke: Macmillan, 1999. p. 28-44.

SEYMOUR, Richard. We Are All Precarious - on the Concept of the 'Precariat' and Its Misuses. New Left Project (2012). Retrieved from: <http://www.newleftproject.org/index.php/site/ article_comments/we_are_all_precarious_on_the_concept_of_the_precariat_and_its_misuses>. STANDING, Guy. Work after Globalization: Building Occupational Citizenship. Cheltenham: Edward Elgar, 2009.

. The Precariat: The New Dangerous Class. The Precariat. London: Bloomsbury, 2011. . O Precariado: A Nova Classe Perigosa. Trad. Cristina Antunes. Belo Horizonte; São Paulo: Autêntica, 2013.

. O precariado e a luta de classes. Revista Crítica de Ciências Sociais, n. 103, p. 9-24, 2014.

A Precariat Charter: From Denizens to Citizens. London; New York: Bloomsbury Academic, 2014.

STÅLSETT, Sturla J. Vulnerabilidad, dignidad y justicia: Valores éticos fundamentales en un mundo globalizado. Pasos, n. 111, p. 13-19, 2004.

. Offering on-Time Deliverance: The Pathos of Neo-Pentecostalism and the Spirits of

Gloobalization. In: (ed.). Spirits of Globalisation. The Growth of Pentecostalism and

Experiential Spiritualities in a Global Age. London: SCM, 2006. p. 198-212.

. (ed.). Religion in a Globalised Age: Transfers and Transformations, Integration and

Resistance. Oslo: Novus, 2008.

. Fearing the Faith of Others? On Government, Religion and Integration - the Case of

Norway. In: SCHMIEDEL, U.; SMITH, G. (ed.). Religion in the European Refugee Crisis. Basingstoke: Palgrave Macmillan, 2018. p. 105-120.

.The Ethics of Vulnerability, Social Inclusion and Social Capital. Forum for development studies 34, n. 1, p. 45-62, 2007.

. Towards a Political Theology of Vulnerability: Anthropological and Theological Propositions. Political Theology 16, n. 5, p. 464-478, 2015.

. Religion i urolige tider. Globalisering, religiøsitet og sårbarhet. Oslo: Cappelen Damm Akademisk, 2017.

; LEIRVIK, Oddbjørn (ed.). The Power of Faiths in Global Politics. Oslo: Novus, 2004.

TAGGART, Paul A. Populism. Concepts in the Social Sciences. Buckingham: Open University, 2000. 